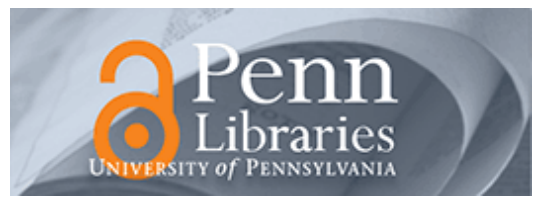

University of Pennsylvania ScholarlyCommons

3-2002

\title{
Multilingual Language Policies and the Continua of Biliteracy: An Ecological Approach
}

Nancy H. Hornberger

University of Pennsylvania, nancyh@gse.upenn.edu

Follow this and additional works at: https://repository.upenn.edu/gse_pubs

Part of the Bilingual, Multilingual, and Multicultural Education Commons, Curriculum and Social Inquiry Commons, Education Policy Commons, International and Comparative Education Commons, and the Latin American Studies Commons

\section{Recommended Citation}

Hornberger, N. H. (2002). Multilingual Language Policies and the Continua of Biliteracy: An Ecological Approach. Language Policy, 1 (1), 27-51. http://dx.doi.org/10.1023/A:1014548611951

This paper is posted at ScholarlyCommons. https://repository.upenn.edu/gse_pubs/316

For more information, please contact repository@pobox.upenn.edu. 


\title{
Multilingual Language Policies and the Continua of Biliteracy: An Ecological Approach
}

\author{
Abstract \\ The one language-one nation ideology of language policy and national identity is no longer the only \\ available one worldwide (if it ever was). Multilingual language policies which recognize ethnic and \\ linguistic pluralism as resources for nation-building are increasingly in evidence. These policies, many of \\ which envision implementation through bilingual intercultural education, open up new worlds of \\ possibility for oppressed indigenous and immigrant languages and their speakers, transforming former \\ homogenizing and assimilationist policy discourses into discourses about diversity and emancipation. \\ This paper uses the metaphor of ecology of language to explore the ideologies underlying multilingual \\ language policies, and the continua of biliteracy framework as ecological heuristic for situating the \\ challenges faced in implementing them. Specifically, the paper considers community and classroom \\ challenges inherent in implementing these new ideologies, as they are evident in two nations which \\ introduced transformative policies in the early 1990s: post-apartheid South Africa's new Constitution of \\ 1993 and Bolivia's National Education Reform of 1994. It concludes with implications for multilingual \\ language policies in the United States and elsewhere.
}

\section{Keywords}

assimilationism, bilingual education, biliteracy, Bolivia, ecology of language, heritage languages, ideology, multilingualism, pluralism, South Africa

\section{Disciplines}

Bilingual, Multilingual, and Multicultural Education | Curriculum and Social Inquiry | Education | Education Policy | International and Comparative Education | Latin American Studies 
Hornberger, N. (2002). Multilingual language policies and the continua of biliteracy:

An ecological approach. Language Policy, 1(1), 27-51.

http://dx.doi.org/10.1023/A:1014548611951

Multilingual language policies and the continua of biliteracy:

An ecological approach

\author{
Nancy H. Hornberger \\ University of Pennsylvania \\ 3700 Walnut Street \\ Philadelphia, PA 19104-6216 \\ 215/898-7957 (phone \& fax) \\ nancyh@gse.upenn.edu
}




\begin{abstract}
The one language-one nation ideology of language policy and national identity is no longer the only available one worldwide (if it ever was). Multilingual language policies which recognize ethnic and linguistic pluralism as resources for nation-building are increasingly in evidence. These policies, many of which envision implementation through bilingual intercultural education, open up new worlds of possibility for oppressed indigenous and immigrant languages and their speakers, transforming former homogenizing and assimilationist policy discourses into discourses about diversity and emancipation. This paper uses the metaphor of ecology of language to explore the ideologies underlying multilingual language policies, and the continua of biliteracy framework as ecological heuristic for situating the challenges faced in implementing them. Specifically, the paper considers community and classroom challenges inherent in implementing these new ideologies, as they are evident in two nations which introduced transformative policies in the early 1990s: post-apartheid South Africa's new Constitution of 1993 and Bolivia's National Education Reform of 1994. It concludes with implications for multilingual language policies in the United States and elsewhere. Key words: assimilationism, bilingual education, biliteracy, Bolivia, ecology of language, heritage languages, ideology, multilingualism, pluralism, South Africa.
\end{abstract}

\title{
Abbreviations:
}

PRAESA Project for the Study of Alternative Education in South Africa PROEIB-Andes Programa de formación en Educación Intercultural Bilingüe para los Paises Andinos, Andean Graduate Program in Bilingual Intercultural Education 


\section{Introduction}

Two scenes from the year 2000:

18 July 2000, Johannesburg, South Africa. In the course of my two-week visit at Rand Afrikaans University, I meet early this Tuesday morning (7:30 am) with a group of young pre-service teachers enrolled in a one-year Diploma in Education

program. The university has been bilingual from its founding, offering instruction in Afrikaans and English in a parallel dual medium format; in the post-apartheid period, rapidly expanding numbers of speakers of diverse African languages have enrolled.

About 20 students attend this English Language Pedagogy class where I have been invited to speak about bilingual education. Their teacher Judy is present, as is my host Elizabeth. At one point, I mention my dissertation research which documented "classroom success but policy failure" for an experimental bilingual education program in Quechua speaking communities of Puno, Peru. The policy failure, I suggest, was at least partly due to some community members' resistance to the use of Quechua in school, which they had always regarded as a Spanish domain. Taking off from this, Judy asks what one can do about negative community attitudes which impede top-down language planning, citing the case of Black African parental demands for English-medium instruction in the face of South Africa's new multilingual language policy. 
Later, when the discussion turns to the importance of the teacher's recognizing and valuing students' languages and cultures even if they're not the teacher's own, Elizabeth takes the opportunity to demonstrate one such practice. Students are instructed to break into small groups to talk to each other about bilingual education for two-three minutes in their own languages. The result: four Nguni speakers (one Zulu, one Xhosa, two Swati), two Gujarati speaking women, three Afrikaans speakers, and one Portuguese speaker (who talks with me) form groups, while the rest of the class members chat to each other in small groups in English. The students clearly enjoy this activity and it generates lively whole class discussion.

17 August 2000, La Paz, Bolivia. On the first day of a three-day Taller de reflexión y análisis sobre la enseñanza de castellano como segunda lengua (Workshop of reflection and analysis on the teaching of Spanish as a second language), the Vice-Minister of Education welcomes workshop participants, emphasizing to us that the key to the Bolivian Education Reform is Bilingual Intercultural Education, and the key to that is Spanish as a Second Language. In recent months, she tells us, questions have been raised about the Reform's attention to indigenous languages, and indigenous parents have begun to demand that their children be taught Spanish. Perhaps the Reform erred, she says, in emphasizing the indigenous languages to such a degree that bilingual education appeared to the public to be monolingual indigenous language education. 
There are approximately 45 participants in the workshop: 15 technical experts from the Curricular Development Unit of the Ministry, a half-dozen representatives from PROEIB, the Andean regional graduate program in bilingual intercultural education at the University of San Simón in Cochabamba, Bolivia, another 8-9 Bolivian pedagogical experts, and about a dozen international specialists in bilingual and second language education (from Brasil, Chile, Ecuador, Mexico, Peru, Belgium, Germany, USA, and Sweden). Many of us had participated five years earlier in a similar workshop on the curriculum and materials for the teaching of the indigenous languages, principally the three largest languages Quechua, Aymara, and Guarani. The materials we reviewed then have been under implementation in the schools for a couple of years now.

Our charge this time is to review the Spanish as a Second Language curriculum and materials developed by the Curricular Development Unit and to make recommendations for improvement in design and implementation. Among the materials available for review are curricular guides, teaching modules for Spanish, bilingual modules for the content areas, cassette tapes and laminated posters, an 80-book class library, a literary anthology, and a series of six big books in Spanish, three of them based on traditional Quechua, Aymara, and Guarani folktales.

In the ensuing three days of intensive work across long hours ( 8 am to $9 \mathrm{pm}$ ), discussions are remarkable for the honesty and integrity with which the Curricular 
Development Unit experts welcome critical scrutiny of their work. These experts worry about how best to teach Spanish to a school population which in many cases has little to no exposure to oral Spanish or to print media outside of the classroom; and so have opted for a richly communicative and literature-based curriculum design. Some of the second language experts are concerned that there is not enough explicit grammatical and lexical instruction and that the syllabus is not sufficiently incremental. Concerns from those who have seen the materials in use in the field are of a different nature. They ask questions like: what are the implications for second language learning of teachers' frequent code-mixing in class, code-mixing prompted by the desire to communicate with the students in a language they understand?; by the same token, what are the implications for maintaining and strengthening the indigenous languages if one and the same teacher teaches in both the indigenous language and Spanish?

As these scenes readily show, the one language - one nation ideology of language policy and national identity is no longer the only available one worldwide (if it ever was). Multilingual language policies which recognize ethnic and linguistic pluralism as resources for nation-building are increasingly in evidence. These policies, many of which envision implementation through bilingual intercultural education, open up new worlds of possibility for oppressed indigenous and immigrant languages and their speakers, transforming former homogenizing and assimilationist policy discourse into discourses about diversity and emancipation. This paper points to two broad sets of 
Multilingual language policies

challenges inherent in implementing these new ideologies, as they are evident in two nations which undertook these transformations in the early 1990s.

Post-apartheid South Africa's new Constitution of 1993 embraces language as a basic human right and multilingualism as a national resource, raising nine major African languages to national official status alongside English and Afrikaans $;{ }^{1}$ this, along with the dismantling of the apartheid educational system, has led to the burgeoning of multilingual, multicultural student populations in classrooms, schools, and universities nationwide. The Bolivian National Education Reform of 1994 envisions a comprehensive transformation of Bolivia's educational system, including the introduction of all thirty of Bolivia's indigenous languages alongside Spanish as subjects and media of instruction in all Bolivian schools. Yet, to transform a standardizing education into a diversifying one and to construct a national identity that is multilingual and multicultural constitute ideological paradoxes which are a challenge to implement.

Recently, scholars are increasingly turning to the metaphor of ecology to think and talk about language planning, teaching, and learning in multilingual settings. In the first part of the paper, I explore salient themes of that metaphor --namely language evolution, language environment, and language endangerment-- and argue that multilingual language policies are essentially about opening up ideological and implementational space in the environment for as many languages as possible, and in particular endangered

\footnotetext{
${ }^{1}$ The nine languages are: Ndebele, Northern Sotho, Southern Sotho, Swati, Tsonga, Tswana, Venda, Xhosa, and Zulu.
} 
Multilingual language policies

languages, to evolve and flourish rather than dwindle and disappear. In the second half of the paper, I use my continua of biliteracy model as heuristic to consider two broad sets of challenges facing these multilingual language policies (as exemplified in the above scenes) and suggest that there is urgent need for language educators, language planners, and language users to fill those ideological and implementational spaces as richly and fully as possible, before they close in on us again. ${ }^{2}$

\section{Multilingual language policies, ideology, and the ecology of language}

The one nation - one language ideology, the idea that a nation-state should be unified by one common language, has held sway in recent Western history from the rise of the European and American nation-states in the $18^{\text {th }}$ and $19^{\text {th }}$ centuries on through the formation of independent African and Asian nation-states in mid- $20^{\text {th }}$ century and up to the present. Fishman wrote of the several score new members brought into the family of nations in the mid- $20^{\text {th }}$ century and of the nationistic and nationalistic ideologies underlying their choice of a national language: "nationism - as distinguished from nationalism - is primarily concerned not with ethnic authenticity but with operational efficiency" (1969: 113). In either case, emphasis was on choosing a national language,

\footnotetext{
${ }^{2}$ In my usage here, "language educators" includes linguists and researchers on language education, language teachers, language teacher educators, and others; "language planners" includes both top-down and bottom-up, organizational and individual agents of language planning; and "language users" includes learners, parents, community members, and others. In other words, I take an inclusive view of those who should be involved in the efforts described here.
} 
Multilingual language policies

one national language, whether it were a Language of Wider Communication serving nationistic goals or an indigenous language serving nationalistic ones.

Yet the one language-one nation equation is increasingly recognized as an ideological red herring (Woolard and Schieffelin 1994: 60-61). For one thing, it is a relatively recent phenomenon when seen against the backdrop of human history. Referring not only to the Greek, Roman, Aztec, and Inca empires of ancient times but also to the more recent Austro-Hungarian and Ottoman empires, May writes in his recent book on the politics of language that "empires were quite happy ... to leave unmolested the plethora of cultures and languages subsumed within them - as long as taxes were paid" (May 2001: 6).

Furthermore, in our day, twin pressures of globalization and ethnic fragmentation exert pressures on the one language-one nation ideology. May suggests that modern nationstates have had to reassess the limits of their sovereignty as a result of the rise of globalisation and the "burgeoning influence of multinational corporations and supranational political organisations," while at the same time minority groups increasingly exert their rights "either to form their own nation-states ... or for greater representation within existing nation-state structures" (2001: 7). In like vein, Freeland notes that Latin American nations are particularly prone to two frequently mentioned effects of globalization from without and within: (1) the weakening of the state from the surge of transnational phenomena and (2) the weakening of the state from social and ethnic fragmentation (1996: 168). Certainly, African nations are similarly prone to these effects. 
Multilingual language policies

Gal suggests what might be considered a linguistic corollary to these pressures when she notes that global processes like colonization, the expansion of capitalism and transnational labor migration have replaced earlier processes of "dispersion of populations and the peopling of the world," such that: 1) the characteristic form of language change in the modern era is the coming together of languages; and 2) the former "relatively egalitarian linguistic diversity, based on small-scale languages whose speakers believe their own language to be superior, [has been changed] into stratified diversity: Local languages are abandoned or subordinated to 'world languages' in diglossic relations..." (1989:356). All of this points to two countervailing trends working together to break apart the one language-one nation ideology: the rise of English as a global language, hence infringing on national languages; and the reclaiming of endangered indigenous, immigrant, and ethnic languages at local and national levels, hence undermining the ascendancy of national languages.

\section{Ecology of language}

As the one language-one nation ideology breaks apart, so too the language planning field increasingly seeks models and metaphors that reflect a multilingual rather than monolingual approach to language planning and policy. One such model is the continua of biliteracy (to be taken up below) and one such metaphor is the ecology of language; both are premised on a view of multilingualism as a resource. Ruiz, like Fishman (1966a) before him, drew our attention to the potential of a language-as-resource ideology as an alternative to the dominant language-as-problem and language-as-right ideological orientations in language planning (1984). Mühlhäusler argues that "language 
Multilingual language policies

planning until the 1980s was based on the premise that linguistic diversity is a problem" (1996: 311-312), but that it is now undergoing a conceptual shift toward recognizing linguistic diversity as an asset.

Einar Haugen is generally credited for introducing the ecology of language in his 1970 paper by that title (Haugen 1972). Haugen himself points to an earlier, 1964 paper by Carl and Frances Voegelin, who suggested that "in linguistic ecology, one begins not with a particular language but with a particular area, not with selective attention to a few languages but with comprehensive attention to all the languages in the area" (Voegelin and Voegelin 1964: 2). ${ }^{3}$ For his part, Haugen defines language ecology as "the study of interactions between any given language and its environment," going on to define the environment of the language as including both psychological ("its interaction with other languages in the minds of bi- and multilingual speakers") and sociological ("its interaction with the society in which it functions as a medium of communication") aspects (1972: 325). He emphasizes the reciprocity between language and environment, noting that what is needed is not only a description of the social and psychological situation of each language, but also the effect of this situation on the language (1972: 334). Haugen argues for the heuristic value of earlier biological, instrumental and structural metaphors in understanding the life, purpose, and form of languages and goes on to invoke the tradition of research in human ecology as a metaphor for an approach which would comprise not just the science of language description, but also concern for language cultivation and preservation (1972: 326-329). He concludes with a

\footnotetext{
${ }^{3}$ Van Lier 2000 cites Trim 1959 as the first reference to ecology of language.
} 
Multilingual language policies

comprehensive catalogue of ecological questions which Mühlhäusler later repeats (Haugen 1972: 336-337; Mühlhäusler 1996: 3-4).

For my purposes here, I am primarily interested in three themes of the ecology metaphor which are salient to me in writings on the ecology of language; all of them are present in Haugen's original formulation. These are: that languages, like living species, evolve, grow, change, live, and die in relation to other languages and also in relation to their environment; for ease of reference, I will call these the language evolution and language environment themes. A third theme is the notion that some languages, like some species and environments, may be endangered and that the ecology movement is about not only studying and describing those potential losses, but also counteracting them; this I will call the language endangerment theme. ${ }^{4}$

In his 1996 book, Linguistic Ecology, Mühlhäusler advocates an ecological approach to languages which, like Haugen's approach, encompasses all three of these metaphorical themes. He argues that our focus must shift from consideration of "given," countable languages to one on human communication in a holistic sense (1996: 8-9) and proposes

\footnotetext{
${ }^{4}$ In recent and forthcoming volumes (Huss, Camilleri and King, 2001; Liddicoat and Bryant 2001; Maffi 2001; Nettle and Romaine 2000; Skutnabb-Kangas 2000), scholars posit an ecology of language in not only a metaphorical sense but also a literal one, explicitly linking the maintenance of linguistic and cultural diversity with the protection and defense of biological and environmental diversity. While I may share their views, that is not the focus of this paper.
} 
Multilingual language policies

an approach which "investigates the support system for a structural ecology of language rather than individual languages" (1996: 312-313); that is, he argues for consideration of language evolution. He "sees the well-being of individual languages or communication networks as dependent on a range of language-external factors as well as the presence of other languages" (1996: 49) and claims that "the focus of inquiry should be upon the functional relationship between the factors that affect the general interrelationship between languages rather than individual factors impacting on individual languages" (1996: 313); that is, he calls for a focus on language environment. Writing from a concern for the decline and loss of linguistic heterogeneity in the world, Mühlhäusler argues for applying ecological theory to the goal of language maintenance (1996: 311324); that is, he writes from a concern for language endangerment, in the sense of both studying and counteracting language loss. He applauds the ecological metaphor for being action-oriented and prefers the partial and local explanations of an ecological approach to the complex yet ultimately mechanical explanations of a systems metaphor (1996: 2).

Others writing on an ecological approach to language planning elaborate on one or more of the metaphorical themes. Kaplan and Baldauf's work elaborates on the language evolution and language environment themes. They emphasize that language planning activity cannot be limited to one language in isolation from all the other languages in the environment (1997: 271). Their model representing the various forces at work in a linguistic eco-system includes "language modification constructs" (1997: 289) or "language change elements" (1997: 296) such as language death, survival, change, revival, shift and spread, amalgamation, contact, pidgin and creole development, and 
Multilingual language policies

literacy development, all processes of what I am here calling language evolution. With regard to language environment, the model also depicts agencies such as government and non-government organisations, education agencies, and communities of speakers, all of which have an impact on the multiple languages in the linguistic eco-system (1997: 311). "Language planning ... is a question of trying to manage the language ecology of a particular language to support it within the vast cultural, educational, historical, demographic, political, social structure in which language policy formulation occurs every day" (1997: 13); "language planning activity must be perceived as implicating a wide range of languages and of modifications occurring simultaneously over the mix of languages in the environment - that is, implicating the total language eco-system" (1997: 296).

Recent work by Phillipson and Skutnabb-Kangas (1996) and Ricento (2000) highlights the language endangerment theme of the ecology metaphor. Phillipson and SkutnabbKangas contrast two language policy options with regard to English worldwide: the diffusion of English paradigm characterized by a "monolingual view of modernization and internationalization" and the ecology-of-language paradigm which involves "building on linguistic diversity worldwide, promoting multilingualism and foreign language learning, and granting linguistic human rights to speakers of all languages" (1996: 429). The juxtaposition of the linguistic imperialism of English over against multilingualism and linguistic human rights is clearly founded on a concern for the ongoing endangerment of many languages, displaced by one or a select few, and the need to counteract that endangerment and displacement. Mühlhäusler cites Pakir's (1991) term 
Multilingual language policies

"killer languages" in reference to the displacing effect of imperial English as well as other languages such as Mandarin, Spanish, French, and Indonesian.

In parallel fashion, van Lier (2000) argues that an ecological approach to language learning emphasizes emergent language development; learning and cognition as explained not only in terms of processes inside the head, but also in terms of interaction with the environment; and learners' perceptual and social activity as, in a fundamental way, their learning. These three emphases can be understood as microlevel, sociocultural language learning parallels to the language evolution, environment, and endangerment themes in an ecological approach to language planning. Bringing sociocultural and sociolinguistic strands together in his ecological approach to literacy, Barton (1994:2932) provides a succinct and useful review of the use of the ecology metaphor in both pscyhological and social traditions in the social sciences.

Ricento argues that as the macro sociopolitical context of language planning has moved over the last several decades from decolonization through modernization and into the new world order, and as social science epistemologies have simultaneously moved from structuralism through critical theory and into postmodernism, so too the language planning field has moved from a focus on problem-solving through a concern for access and into an emphasis on linguistic human rights. In words that evoke the language endangerment and language environment themes outlined above, he suggests that the ecology-of-language paradigm may well be the conceptual framework for language planning in the future, precisely because of its emphasis on language rights and on 
Multilingual language policies

connecting macro sociopolitical processes with microlevel patterns of language use (2000: 208-209).

In sum, an ecology of language metaphor captures a set of ideological underpinnings for a multilingual language policy, in which languages are understood to (1) live and evolve in an eco-system along with other languages (language evolution), (2) interact with their sociopolitical, economic, and cultural environments (language environment), and (3) become endangered if there is inadequate environmental support for them vis-à-vis other languages in the eco-system (language endangerment). All three of these ideological themes come into play in the following consideration of challenges facing the implementation of multilingual language policies in South Africa and Bolivia.

\section{Multilingual language policies and the continua of biliteracy: Implementation in classroom and community}

The scenes from South Africa and Bolivia which opened this paper evoke broad sets of challenges at community and classroom levels. In the first instance, there are the challenges of confronting community attitudes favoring the language of power in the society, attitudes which are at odds with developmental evidence that children learn best from the starting point of their own language(s). There are also the challenges, at classroom level, of providing materials and interaction in multiple languages which are not necessarily spoken by all participants. In the continua of biliteracy model, the latter 
Multilingual language policies

challenges relate to media and content of biliteracy, and the former to biliteracy development and contexts.

The continua of biliteracy is a comprehensive, ecological model I have proposed as a way to situate research, teaching, and language planning in multilingual settings. The continua of biliteracy model defines biliteracy as "any and all instances in which communication occurs in two (or more) languages in or around writing" (Hornberger 1990: 213) and describes it in terms of four nested sets of intersecting continua characterizing the contexts, media, content, and development of biliteracy (Hornberger 1989a; Hornberger and Skilton-Sylvester 2000). Specifically, it depicts the development of biliteracy along intersecting first language - second language, receptive-productive, and oral-written language skills continua; through the medium of two (or more) languages and literacies whose linguistic structures vary from similar to dissimilar, whose scripts range from convergent to divergent, and to which the developing biliterate individual's exposure varies from simultaneous to successive; in contexts that encompass micro to macro levels and are characterized by varying mixes along the monolingualbilingual and oral-literate continua; and with content that ranges from majority to minority perspectives and experiences, literary to vernacular styles and genres, and decontextualized to contextualized language texts (See Figures 1 and 2).

The notion of continuum conveys that all points on a particular continuum are interrelated, and the model suggests that the more their learning contexts and contexts of use allow learners and users to draw from across the whole of each and every continuum, 
the greater are the chances for their full biliterate development and expression (Hornberger 1989a: 289). Implicit in that suggestion is a recognition that there has usually not been attention to all points. In educational policy and practice regarding biliteracy, there tends to be an implicit privileging of one end of the continua over the other such that one end of each continuum is associated with more power than the other, for example written development over oral development (Figure 3 depicts the traditional power weighting assigned to the different continua). There is a need to contest the traditional power weighting of the continua by paying attention to and granting agency and voice to actors and practices at what have traditionally been the less powerful ends of the continua (Hornberger and Skilton-Sylvester 2000).

As noted earlier, the continua of biliteracy model, like the ecology of language metaphor, is premised on a view of multilingualism as a resource. Further, as the above overview reveals, the continua of biliteracy model also incorporates the language evolution, language environment, and language endangerment themes of the ecology of language metaphor. The very notion of bi (or multi)-literacy assumes that one language and literacy is developing in relation to one or more other languages and literacies (language evolution); the model situates biliteracy development (whether in the individual, classroom, community, or society) in relation to the contexts, media, and content in and through which it develops (i.e. language environment); and it provides a heuristic for addressing the unequal balance of power across languages and literacies (i.e. for both studying and counteracting language endangerment). 
Multilingual language policies

Biliteracy development and contexts: Language and power in the community

Judy asked what one can do about negative community attitudes toward South Africa's multilingual language policy, referring specifically to Zulu, Xhosa or other Black African parental demands for English-medium instruction for their children. The Bolivian ViceMinister of Education suggested that the National Education Reform might have erred in placing too much emphasis on indigenous language instruction at the outset, while neglecting instruction in Spanish as a second language. In both cases, the zeal of educators and policy makers for teaching children literacy on the foundation of a language they already speak appears to be at odds with a popular demand for the language of power.

The challenge of popular demand for the societal language of power is a very real one in contexts all over the world, one not to be lightly dismissed. In terms of the continua model, case after case shows that societal power relationships tend to favor the macro, literate, and monolingual ends of the context continua; and national policy and school curricula tend to focus primarily on second language, written, productive skills in biliterate development.

My dissertation study in Puno, Peru in the 1980s had documented Quechua-speaking community members' resistance to the implementation of Quechua as a medium of instruction in the schools for ideological reasons largely having to do with Spanish being seen as the language of formal education and thereby of access to socioeconomic 
Multilingual language policies

mobility and power (Hornberger 1987, 1988a, 1988b). I concluded that unless the wider societal context could be geared toward valuing Quechua on a par with Spanish, "policy failure" was inevitable; the schools, however well they might implement bilingual education, could not on their own counteract deep-seated ideologies favoring Spanish. Those same, enduring ideologies are the ones that the Bolivian Vice-Minister indexed in her opening comments at the Workshop last summer, referring to Quechua and Aymara speaking communities of Bolivia some twenty years after my study in Peru; these ideologies still thrive throughout indigenous communities of the Andes.

Several South African scholars have recently documented or made reference to a similar set of ideologies in Black African communities of South Africa. There, English is the language of power, undergirded not only by the worldwide hegemony of English but also by the heritage of apartheid education which left in its wake a deep suspicion of mother tongue education. Banda explores the paradox whereby black and coloured parents increasingly demand English medium instruction even while academics and researchers agree that English medium instruction is largely responsible for "the general lack of academic skills and intellectual growth among blacks at high school and tertiary levels" (2000: 51); and he considers what would be needed to implement a truly additive bilingual policy. De Klerk undertook a survey and interview study in Grahamstown in the Eastern Cape Province, focusing on Xhosa-speaking parents' decisions to send their children to English-medium schools; among the reasons parents gave for choosing an English school for their children were the need for a better education, the recognition that 
Multilingual language policies

English is an international language and the hope that English would open the door to more job opportunities for their children (2000: 204-205).

Interestingly, both Bolivia and South Africa have opened up implementational space for popular participation in establishing school language policies, South Africa via the School Governing Boards and Bolivia via the Comités which are part of the Popular Participation provisions of the Education Reform. The goal is to empower parents to make their own decisions about what languages will be medium and subject of instruction in their children's schools. Yet, it would appear that the implementational space for popular participation is of little avail in advancing a multilingual language policy if it is not accompanied by popular participation in the ideological space as well.

In a study carried out in six newly integrated schools in Durban in Kwazulu-Natal Province, Chick and McKay found a pervasive English-only discourse (along with a decline of standards discourse and a one-at-a-time discourse of classroom interaction) affecting classroom teaching. English-only discourse was evident for example in principals' and teachers' rejection of the use of Zulu in classes other than in Zulu lessons, a practice for which they cited as reasons that students need to improve their English, that students need English for economic advancement, and that the African National Congress itself uses English as a means of reconciling rival ethnic groups ( at odds with the ANC's publicly stated position) (Chick 2000). Yet, the same study also found evidence of counter discourses, namely a multicultural discourse and a collaborative, group work discourse. "A number of teachers, primarily younger teachers, stated that they have 
Multilingual language policies

discovered that the judicious use of Zulu in classrooms can be beneficial and are permitting the use of Zulu even when it runs counter to school policy" (2000:7); and one teacher in a former Indian elementary school had started doing more group work since attending an in-service workshop on Outcomes-Based Education, finding it advantageous in that quick progress can be made when "brighter and more fluent learners can explain to others exactly what is required" (2000:12). Chick attributes the emergence of these new discourses among teachers to the ideological space which the new language policies opened up (2000: 13).

Similarly, while Bloch and Alexander acknowledge that the languages of South Africa are situated along the macro-micro context continuum with English at the most macro (powerful) end and the indigenous African languages clustered at the most micro (powerless) end, with Afrikaans somewhere along the middle, they go on to make clear that what is at stake with the new multilingual language policy is the "gradual shift of power towards the languages of the majority of the people, who continue in linguistic terms to be treated as a social minority" (2001: 5). They report on the work of their PRAESA $^{5}$ group at Battswood Primary School in Cape Town, where the "intention is to develop, try out, and demonstrate workable strategies for teaching and learning, using

\footnotetext{
${ }^{5}$ PRAESA is the Project for the Study of Alternative Education in South Africa, directed by Neville Alexander and based at the University of Cape Town. The team at Battswood Primary School includes one PRAESA staff member (Carole Bloch), assisted sometimes by a post-graduate student, a Xhosa speaking teacher, Ntombizanele Nkence, and a resident Battswood teacher, Erica Fellies (Bloch and Alexander 2001:11).
} 
additive bilingualism approaches"; they see themselves as working at the "less powerful micro, oral, and multilingual ends [of the context continua] as [they] develop ways to challenge the power relations that exist at macro, literate, and monolingual English levels of the continua in the school and the wider society" (2001:10).

What then does the continua model tell us about what to do in cases such as those depicted in the opening vignettes? The work of Chick and McKay and of Bloch and Alexander is consistent with the argument from the continua model that what is needed is attention to oral, multilingual interaction at the micro level of context and to learners' first language, oral, and receptive language skills development (that is, to the traditionally less powerful ends of the continua of context and development). It is consistent as well with the "classroom success" story that my dissertation told alongside the "policy failure" account referred to above (Hornberger 1987). That is, despite the ideological privileging of Spanish for school contexts, Quechua speaking children were seen then (and continue today) to clearly thrive from the greater participation in oral classroom interaction which receptive and productive use of their first language afforded them (Hornberger 1988a, $1989 b$ ). In other words, what is needed is to find as many ways as possible to open up ideological spaces for multiple languages and literacies in classroom, community, and society. The continua model is a heuristic to assist in that ecological endeavor. We turn now to consideration of the media and content through which this can be accomplished and the power imbalance among languages subverted.

\section{Media and content of biliteracy: Language and identity in the classroom}

South African Professor Elizabeth encouraged her young pre-service teachers to speak and use their languages to discuss their own educational experiences and views in the 
classroom, thereby modeling a practice they might use with their own multilingual, multicultural students in the future. The Bolivian Curricular Development Unit experts sought to provide richly communicative and literature-based curriculum and materials for indigenous language speakers to learn Spanish, and raised questions about the implications of code-mixing practices in classroom interaction. In both cases, the negotiation of multiple languages, cultures, and identities among learners (and teachers) who bring different resources to the classroom, is at issue.

The challenge of negotiating across multiple languages, cultures, and identities is a very real one in classrooms all over the world, one not to be lightly dismissed. Yet, on the whole, educational policy and practice continues blithely to disregard the presence of multiple languages, cultures, and identities in today's classrooms. In terms of the continua model, case after case shows that majority, literary, decontextualised contents and similar, convergent, standard language varieties as successively acquired media of instruction, are the established and expected norms in educational systems everywhere.

Multilingual language policies offer a stunning contrast to these expectations, opening up a space where minority, vernacular, contextualised contents and identities can be introduced and a range of media -- including dissimilar, divergent, nonstandard varieties as well as visual and other communicative modes -- can be employed simultaneously in instruction. Andean teachers in a course I taught on bilingual intercultural education wrote narratives about some of their experiences along these lines. One teacher opened up a Mother's Day celebration to a child's recitation of a Quechua poem and another 
opened up her language class to the dramatisation of a local story, using local materials and local music. In each case, the results were an impressive display of the learners' talents, accompanied by greater intercultural understanding of all those involved. These teachers made use of media and content that have historically been excluded from the school, and thereby subverted the power imbalance among the languages and literacies in the school environment (Hornberger 2000: 191-192).

Pippa Stein writes along these lines in recounting experiences with two projects she has worked on with pre-service and in-service language teachers in Johannesburg, both of which encourage students' use of a range of representational resources in their meaning making, including the linguistic mode in its written and spoken forms, but also the visual, the gestural, the sonic, and the performative modes (paraphrasing Kress and Van Leeuwen 1996). A reflective practitioner, she is exploring "ways of working as a teacher using certain pedagogies which re-evaluate the value of a resource in the classroom," specifically with the goal of ascribing equal value to resources brought by historically advantaged and historically disadvantaged students. Both the Performing the Literacy Archive Project and the Photographing Literacy Practices Project focus on literacy because "issues of literacy are at the heart of educational success in schools," but in them the students "explore meaning-making in multiple semiotic modes." Drawing on her reflections and on written and video documentation of the students' work over the several years she has done these projects with language teachers, Stein shows how these pedagogies "work with what students bring (their existing resources for representation) and acknowledge what [historically disadvantaged] students have lost." As she puts it, it 
is "the saying of the unsayable, that which has been silenced through loss, anger or dread, which enables students to re-articulate their relationships to their pasts. Through this process of articulation, a new energy is produced which takes people forward. I call this process of articulation and recovery re-sourcing resources" (Stein, to appear).

The PRAESA group has been carrying out another effort at including practices at the traditionally less powerful ends of the content and media continua as resources in instruction in their work at Battswood Primary School with 30 Xhosa and 19 English/Afrikaans bilingual children, as they have progressed from their first days in Grade One up to the present, their third year of primary school. Bloch and Alexander report on this work in the following terms: "Regarding the media of biliteracy, we encourage simultaneous exposure for the Xhosa and English speaking children to both languages with an emphasis on the children's first language... we are concentrating mainly on Xhosa and English, while at the same time not excluding Afrikaans. Our ongoing challenge, in terms of Xhosa language learning for the English/Afrikaans speakers is to try and inspire them enough, and teach the language in ways that motivate them to learn 'against the odds' of any real incentives which promote Xhosa as either necessary or even desirable in the wider society" (2001: 12). As regards the content of biliteracy, "the teachers have had to move from the safety of the decontextualised content of a rigid phonics-based part-to-whole skills programme to face the real evidence of what their pupils actually know and can do, thereby drawing on contextualised, vernacular, minority (i.e. majority) knowledge" (2001: 14-15). 
Multilingual language policies

To carry out these goals, they encourage oral, mother tongue and bilingual interaction; in Grade One, the teachers sang many songs and did rhymes with the whole class, typing up the Xhosa rhymes and songs and putting them in plastic sleeves with an English one on one side and Xhosa on the other so that the children could serve as readers to each other. They use interactive writing and journal writing, with the English and Xhosa speaking teachers and PRAESA staff members writing back to the children in their respective languages, a strategy which has proved to provide powerful motivation for the children's use of both languages in their writing. The teachers read daily stories in both Xhosa and English, and have collected an adequate selection of Xhosa and English picture storybooks, which they encourage the children to read in bilingual pairs. The PRAESA group has begun to identify numerous strengths which such practices develop in the children, while simultaneously confronting the fact that most scholastic assessment tools do not measure the kinds of metalinguistic and interpretive skills which particularly stand out in these children.

What then does the continua model tell us about what to do in cases such as those depicted in the opening vignettes? The work of Stein and of Bloch and Alexander is consistent with the argument from the continua model that what is needed is attention to the diversity of standard and nonstandard language varieties, orthographies, and communicative modes and the range of contextualized, vernacular, minority knowledge resources that learners bring to the classroom (that is, to the traditionally less powerful ends of the continua of media and content). It is consistent as well with the on-theground experience of the Bolivian and South African educators who find that 
Multilingual language policies

multilingual interaction in the classroom is inevitable and desirable if multilingual

learners are to be encouraged to participate -- in the classroom, in academic success, and, ultimately, in a truly democratic society. In other words, what is needed is to find as many ways as possible to open up implementational spaces for multiple languages, literacies, and identities in classroom, community, and society. The continua model is a heuristic to assist in that ecological endeavor.

\section{Conclusion}

Bloch and Alexander express the hope that "the window of opportunity will remain open for another few years and that the multiplication of such projects in different areas of South Africa involving all the different languages .... will shift the balance of power in favour of those for whom ostensibly the democratic transition was initiated" (2001: 25). I share their optimism and their sense of urgency that we linguists and language educators must work hard alongside language planners and language users to fill the ideological and implementational spaces opened up by multilingual language policies; and as researchers to document these new discourses in action so as to keep those ecological policy spaces open into the future.

My sense of urgency about this is perhaps heightened because of recent accumulating events in my own country, where multilingual language policy spaces seem to be closing up at an accelerating rate and the one language-one nation ideology still holds tremendous sway. Analyzing the politics of official English in the $104^{\text {th }}$ Congress of the United States, Joseph Lo Bianco writes of a U.S. discourse which he designates unum 
Multilingual language policies

and which is all about opposing multilingual excess and national disunity, i.e. about homogenization and assimilationism Also present, he found, was a discourse of pluribus, about diversity and emancipation, i.e. about language pluralism (Lo Bianco 2001). Both discourses have arguably always been present in the United States, waxing and waning with the times, an ideological tension captured succinctly in the U.S. motto, E pluribus unum 'out of many one' from which Lo Bianco takes his designations. $^{6}$

Though the United States traditionally has no national language policy, U.S. language ideologies are evident in both national educational policy and state level language policies. In the latter half of the twentieth century, there have been ecological policy spaces for multilingualism and the discourse of pluribus in, for example, the national Bilingual Education Act, now of more than 30 years standing, and in state language policies such as Hawaii's recognition of Hawaiian and English or New Mexico's of Spanish and English. Since 1980, however, when Hayakawa first introduced a proposed English Language Constitutional Amendment in Congress, the discourse of unum has been gaining ground as a growing number of states have passed English-only legislation.

Even more recently, the pace has picked up. At the state level, under the infamous Unz initiative, California and Arizona voters passed anti-bilingual education referenda in 1999 and 2000 respectively. In these states, multilingual language policies were thereby

\footnotetext{
${ }^{6}$ Similarly, Cobarrubias identifies "linguistic assimilation" and "linguistic pluralism" as two typical language ideologies which have long co-existed in tension in the United States (1983: 63).
} 
Multilingual language policies

reversed (or severely curtailed) for ideological reasons before implementation could be fully realized, documented, and tested. In the debates surrounding passage of Proposition 227 in California, it became clear that (1) the public had very little understanding of what bilingual education really is; and (2) much of what passed for bilingual education in California was in fact not. The ideological discourse of unum prevailed over that of pluribus, with very little attention to the facts of institutional implementation. ${ }^{7}$ At the national level, under the Bush administration, the Bilingual Education Act is undergoing threat of revision which would gut its potential to provide multilingual education for thousands of children who speak English as a second language. Instead, the emphasis is on "moving them to English fluency" in a minimal number of years (National Association for Bilingual Education Action Alert, 23 April 2001; 3 May 2001). None of these trends bodes well for the pluralistic discourse of pluribus or a multilingual language ecology in the United States.

Happily, however, there is also a move afoot in recent years among U.S. linguists and language educators to help solidify, support, and promote longstanding grassroots minority language maintenance and revitalization efforts in the United States, under the

\footnotetext{
${ }^{7}$ Similarly, May (2001), analyzing the Welsh case, writes that minority language policy must overcome both institutional and attitudinal difficulties in order to be successfully implemented at state level. That is, the minority language must be institutionalized in the public realm and it must gain attitudinal support from majority language speakers.
} 
rubric of "heritage languages." ${ }^{8}$ The Heritage Language Initiative, which has among its priorities "to help the U.S. education system recognize and develop the heritage language resources of the country" and "to increase dialogue and promote collaboration among a broad range of stakeholders" (http://www .cal.org/heritage/), has thus far sponsored one national research conference in 1999 with plans for another in 2002 (see Wiley and Valdés 2000 for a selection of papers from the first conference). In the intervening years, a working group of scholars was convened to draft a statement of research priorities now being circulated to researchers and policy-makers (available in Wiley and Valdés 2000 and at www.cal.org/heritage); and a bi-national conversation on heritage/community languages between US and Australian scholars took place in Melbourne (http://www.staff.vu.edu.au/languageconf/).

\footnotetext{
${ }^{8}$ While the term "heritage language" has been in use, particularly in Canada, since the early 1970s, a brief search in the Linguistics and Language Behavior Abstracts covering 1973 to 2001 shows that the term has been gaining significant ground in the U.S. only in the last decade and in particular the last five years. Of 120 references, 100 date from 1991 or later; 68 of these from 1997 or later. While the majority of references are still to Canada's heritage languages, there is a growing number of references to U.S. indigenous (e.g. Hawaiian, Navajo, Oneida, Siouan) and immigrant (e.g. Chinese, Korean, Italian, Spanish, Yiddish) languages. Meanwhile, as Colin Baker has noted, the term sometimes carries a negative connotation of pointing to the (ancient, primitive) past rather than to a (modern, technological) future (Baker and Jones 1998: 509); for perhaps this reason and others, the preferred term in Australia is "community languages" (Clyne 1991, Horvath and Vaughn 1991).
} 
Multilingual language policies

This Heritage Language Initiative, supported by both the Center for Applied Linguistics and the National Foreign Language Center, is at least in part about resolving the longstanding language policy paradox whereby we squander our ethnic language resources while lamenting our lack of foreign language resources. It further seeks to draw together and provide visibility and support for the myriad and ongoing bottom-up efforts at rescuing and developing U.S. indigenous and immigrant language resources (as documented in volumes such as Cantoni 1996, Henze and Davis 1999, Hornberger 1996, McCarty and Zepeda 1995, 1998 on U.S. indigenous languages; Fishman 1966b, Kloss 1977, Ferguson and Heath 1981, García and Fishman 1997, McKay and Wong 1988, 2000, Pérez 1998 on U.S. (indigenous and) immigrant languages; Fishman 1991, 2000, May 1999 on cases around the world including U.S. indigenous and immigrant languages).

The Heritage/Community Language effort is one which, I believe, takes an ecological, resource view of indigenous, immigrant, ethnic, and foreign languages as living and evolving in relation to each other and to their environment and as requiring support lest any one of them become further endangered. As linguists and language educators, we need to fill as many ecological spaces as possible, both ideological and implementational, with efforts like these and the Andean and South African efforts mentioned above if we are to keep the multilingual language policy option alive, not only in Bolivia, South Africa, the United States, and Australia, but in all corners of our multilingual world. 
Multilingual language policies 
Multilingual language policies

\section{Acknowledgments}

This paper was originally presented as a plenary talk at the Third International Symposium on Bilingualism, held at the University of the West of England, in Bristol, UK in April 2001. I am grateful to Stephen May and the members of the Organizing Committee for inviting me and providing the opportunity for me to pull these thoughts together; and I thank those present for their comments. I also thank Educational Linguistics Ph.D. student Mihyon Jeon for her thoughtful and detailed response and suggestions on an earlier version of the paper.

My gratitude goes to Professor Elizabeth Henning of Rand Afrikaans University for inviting and hosting me for a two-week visit in conjunction with the Qualitative Research in Education conference there. My thanks also go to Luis Enrique López, Director of PROEIB Andes (Programa de formación en Educación Intercultural Bilingüe para los Paises Andinos, Andean Graduate Program in Bilingual Intercultural Education) and to the Bolivian Ministry of Education for including me as participant in the La Paz Taller described in the Introduction. 
Multilingual language policies

\section{References}

Baker, Colin, \& Jones, Sylvia Prys. (1998). Encyclopedia of Bilingualism and Bilingual Education. Clevedon, UK: Multilingual Matters.

Banda, Felix. (2000). The dilemma of the mother tongue: Prospects for bilingual education in South Africa. Language, Culture and Curriculum, 13(1), 51-66.

Barton, David. (1994). Literacy: An Introduction to the Ecology of Written Language. Oxford, UK: Blackwell Publishers.

Bloch, Carole, \& Alexander, Neville (2001). A luta continua!: The relevance of the continua of biliteracy to South African multilingual schools. Paper presented at Third International Bilingualism Symposium, Bristol, April.

Cantoni, Gina (Ed.). (1996). Stabilizing Indigenous Languages. Flagstaff: Northern Arizona University Center for Excellence in Education.

Chick, Keith. (2000). Constructing a multicultural national identity: South African classrooms as sites of struggle between competing discourses. Paper presented as Nessa Wolfson Colloquium, University of Pennsylvania, November.

Clyne, Michael. (1991). Community Languages: The Australian Experience. Melbourne: Cambridge University Press.

Cobarrubias, Juan. (1983). Ethical issues in status planning. In J. Cobarrubias (Ed.), Progress in language planning (pp. 41-86). Berlin: Mouton.

de Klerk, Vivian. (2000). To be Xhosa or not to be Xhosa ... that is the question. Journal of Multilingual and Multicultural Development, 21(3).

Ferguson, Charles A., \& Heath, Shirley Brice (Eds.). (1981). Language in the USA. New York: Cambridge University Press. 
Multilingual language policies

Fishman, Joshua A. (1966a). Planned reinforcement of language maintenance in the United States; Suggestions for the conservation of a neglected national resource. In J. A. Fishman (Ed.), Langauge Loyalty in the United States: The Maintenance and Perpetuation of non-English Mother Tongues by American Ethnic and Religious Groups (pp. 369-411). The Hague: Mouton.

Fishman, Joshua A. (Ed.) (1966b). Language Loyalty in the United States: The Maintenance and Perpetuation of non-English Mother Tongues by American Ethnic and Religious Groups. The Hague: Mouton.

Fishman, Joshua A. (1969). National languages and languages of wider communication in the developing nations. Anthropological Linguistics, 11(4), 111-135.

Fishman, Joshua A. (1991). Reversing Language Shift: Theoretical and Empirical Foundations of Assistance to Threatened Languages. Clevedon, UK: Multilingual Matters.

Fishman, Joshua A. (Ed.). (2000). Can Threatened Languages be Saved? "Reversing Language Shift" Revisited. Clevedon, UK: Multilingual Matters.

García, Ofelia, \& Fishman, Joshua A. (Eds.). (1997). The Multilingual Apple: Languages in New York City. Berlin: Mouton.

Haugen, Einar. (1972). The Ecology of language. Stanford, CA: Stanford University Press.

Henze, Rosemary, \& Davis, Kathryn A. (Eds.). (1999). Authenticity and Identity: Lessons from Indigenous Language Education. Anthropology and Education Quarterly, 30(1), entire issue. 
Multilingual language policies

Hornberger, Nancy H. (1987). Bilingual education success, but policy failure. Language in Society, 16(2), 205-226.

Hornberger, Nancy H. (1988a). Bilingual education and language maintenance: A southern Peruvian Quechua case. Berlin: Mouton.

Hornberger, Nancy H. (1988b). Language ideology in Quechua communities of Puno, Peru. Anthropological Linguistics, 30(2), 214-235.

Hornberger, Nancy H. (1989a). Continua of biliteracy. Review of Educational Research, 59(3), 271-296.

Hornberger, Nancy H. (1989b). Pupil participation and teacher techniques: Criteria for success in a Peruvian bilingual education program for Quechua children. International Journal of the Sociology of Language, 77, 35-53.

Hornberger, Nancy H. (Ed.). (1996). Indigenous Literacies in the Americas: Language Planning from the Bottom up. Berlin: Mouton.

Hornberger, Nancy H. (2000). Bilingual education policy and practice in the Andes: Ideological paradox and intercultural possibility. Anthropology and Education Quarterly, 31(2), 173-201.

Hornberger, Nancy H., \& Skilton-Sylvester, Ellen. (2000). Revisiting the continua of biliteracy: International and critical perspectives. Language and Education: An International Journal, 14(2), 96-122.

Horvath, Barbara M., \& Vaughan, Paul. (1991). Community Languages: A Handbook. Clevedon, UK: Multilingual Matters.

Huss, Leena, Grima, Antoinette Camilleri, \& King, Kendall (Eds.). (2001). Transcending monolingualism: Linguistic revitalisation in education. Lisse: Swets \& Zeitlinger. 
Multilingual language policies

Kaplan, Robert B., \& Baldauf, Richard B. (1997). Language planning from practice to theory. Clevedon, UK: Multilingual Matters.

Kaplan, Robert B., Baldauf, Jr., Richard B., Liddicoat, Anthony J., Bryant, Pauline, Barbaux, Marie-Thérèse, \& Pütz, Martin. (2000). Editorial. Current Issues in Language Planning, 1(1), 1-10.

Kloss, Heinz. (1977). The American Bilingual Tradition. Rowley, MA: Newbury House.

Kress, Gunther, \& Leeuwen, Theo van. (1996). Reading images: The grammar of visual design. London: Routledge.

Liddicoat, Anthony J., \& Bryant, Pauline, (Eds.). (2001). Language planning and language ecology: A current issue in language planning. Current Issues in Language Planning, 1(3). Entire issue.

Lo Bianco, Joseph. (2001). What is the problem? A study of official English. Paper presented at the annual meetings of the American Association for Applied Linguistics, St. Louis, Missouri.

Maffi, Luisa. (2001). On biocultural diversity: Linking language, knowledge, and the environment. Washington DC: Smithsonian Institution Press.

May, Stephen (Ed.). (1999). Indigenous Community-Based Education. Clevedon, UK: Multilingual Matters.

May, Stephen. (2000). Accommodating and resisting minority language policy: The case of Wales. International Journal of Bilingual Education and Bilingualism, 3(2), 101128.

May, Stephen. (2001). Language and minority rights: Ethnicity, nationalism and the politics of language. Essex, UK: Pearson Education. 
Multilingual language policies

McCarty, Teresa L., \& Zepeda, Ofelia (Eds.). (1995). Indigenous Language Education and Literacy. Bilingual Research Journal, 19(1). Entire issue.

McCarty, Teresa L., \& Zepeda, Ofelia (Eds.). (1998). Indigenous Language Use and Change in the Americas. International Journal of the Sociology of Language, 132. Entire issue.

McKay, Sandra Lee, \& Wong, Sau-Ling (Eds.). (2000). New Immigrants in the United States: Readings for Second Language Educators. New York: Cambridge University Press.

McKay, Sandra Lee, \& Wong, Sau-ling Cynthia (Eds.). (1988). Language Diversity: Problem or Resource? New York: Newbury House.

Mühlhaüsler, Peter. (1996). Linguistic ecology : Language change and linguistic imperialism in the Pacific region. London: Routledge.

Nettle, Daniel, \& Romaine, Suzanne. (2000). Vanishing voices : The extinction of the world's languages. New York: Oxford University Press.

Pakir, Anne (1991) Contribution to workshop on endangered languages, International Conference on Austronesian Linguistics, Hawaii (cited in Muhlhausler 1996)

Pérez, Bertha (Ed.). (1998). Sociocultural Contexts of Language and Literacy. Mahwah, NJ: Lawrence Erlbaum.

Phillipson, Robert, \& Skutnabb-Kangas, Tove. (1996). English only worldwide or language ecology? TESOL Quarterly, 30(3), 429-452.

Ricento, Thomas. (2000). Historical and theoretical perspectives in language policy and planning. Journal of Sociolinguistics, 4(2), 196-213. 
Multilingual language policies

Skutnabb-Kangas, Tove. (2000). Linguistic genocide in education--or worldwide diversity and human rights? Mahwah, NJ:Lawrence Erlbaum.

Stein, Pippa. (to appear). Re-sourcing resources: pedagogy, history and loss in a Johannesburg classroom. In M. Hawkins (Ed.), Social/cultural approaches to language learning, teaching, and teacher education. Clevedon, UK: Multilingual Matters.

Trim, John L. M. (1959). Historical, descriptive and dynamic linguistics. Language and Speech 2, 9-25.

van Lier, Leo. (2000). From input to affordance: Social-interactive learning from an ecological perspective. In J. P. Lantolf (Ed.), Sociocultural theory and second language learning (pp. 245-259). Oxford: Oxford University Press.

Wiley, Terrence \& Valdés, Guadalupe (Eds.) (2000) Heritage Language Instruction in the United States: A Time for Renewal. Bilingual Research Journal 24 (4). Entire issue. 